УДК 35.351

DOI https://doi.org/10.32838/TNU-2663-6468/2020.5/17

\author{
Hrabovenko N.V. \\ Candidate of Pedagogic Sciences, docent, \\ Professor of the Department of Public \\ Administration, Interregional Academy \\ of Personnel Management (IAPM)
}

\title{
MECHANISMS OF IMPLEMENTATION OF THE STATE-PUBLIC MODEL OF EDUCATION MANAGEMENT IN THE ACTIVITIES OF LOCAL GOVERNMENT BODIES
}

\begin{abstract}
The article considers the mechanisms of introduction of the state-public model of education management in the activity of local self-government bodies. It is proved that education management needs constant improvement and modernization, and decentralization, democratization, formation of civil society as processes of the country's development put on the agenda the formation and development of state-public model of education management, mechanisms of its implementation in local government. The necessity of formation of theoretical and methodological bases of research of the role of local self-government bodies in the state-public model of education management in Ukraine, study of foreign experience of participation of local communities in solving educational problems, definition of new approaches to management of all educational activity, especially at local level conditions under which the activities of local governments in implementing a new model of education management will be effective. The concept of "state-public management of education" as a type of interaction between the state and society, the process of combining the activities of the state and community. The purpose of state-public education management is defined-satisfaction of educational needs and realization of the right to access to quality education. Foreign and domestic experience of education management at the regional level is analyzed. It was found that today local governments have some positive experience in involving the public, holding consultations, establishing collegial bodies at local councils, holding public discussions and general meetings. It is proved that education management in most foreign countries (Great Britain, Latvia, Germany, Poland, USA, Finland, France) is carried out in compliance with the principle of decentralization with the transfer of most state functions to local governments, NGOs and the private sector.
\end{abstract}

Key words: education, state-public management of education, quality of education, local selfgovernment. decentralization of education management.

Formulation of the problem. Modern education plays an important role in the formation and development of the individual, so the task of any democratic state is to ensure equal access to quality education throughout life. This approach will in the future pursue the potential of the individual and ensure a decent living standard.

Management of education needs constant improvement and rapid modernization, considering social changes and reforms in the country. Decentralization, democratization, formation of civil society are the integral part of the country's development. They raise issues of the formation and development of the state-public education management model, its implementation mechanisms in the local governments' activities.

This reflects the fact, that the decentralization principles require a redistribution of powers between the state, regional and basic levels of education management. In addition, the public is another element of the management system. Today, the statepublic model of education management must ensure equality of all subjects, be open and democratic. The relevance of state and public education management is determined by changes in the socio-political structure of our country, which necessitate a new educational policy aimed at building a democratic state and meeting the educational needs of citizens of independent Ukraine.

The role of local government authorities in the state-public model of education management is to provide conditions for accelerated, innovative education development and self-realization of the individual. In such circumstances, it is especially important to form convincing theoretical and methodological foundations for studying the role 
of local governments in the state-public model of education management in Ukraine and to study foreign experience of local communities in solving educational problems. It is also highly significant to identify new approaches to managing all educational activities and analyze the conditions under which the local governments' activities in implementing a new education management model will be effective.

The National Strategy for Education Development in Ukraine until 2021, approved by the Decree of the President of Ukraine in June 25, 2013 № 344/2013, states the need to create a flexible and effective public administration system that will ensure intensive development and quality of education, as well as its focus on meeting the needs of the state and individual.

It is also determined that education management should be based on innovative strategies in accordance with the principles of sustainable development as well as creation of modern systems of educational projects and their monitoring. It should also be based on development of an education public administration model, in which the individual, society and the state become equal subjects and partners.

Analysis of recent research and publications. Some theoretical and practical aspects of regional and local government activities were researched in the works of Deikun D., Yelnikova G., Zaichenko O., Kalinina L., Mazak A. and others.

The issues of public administration in education were studied in the works of Bochkarev V., Goshko A., Grabovsky V., Yelnikova G., Komarnytsky M., Knyazev V., Shamova T. and others.

Pastovensky O. analyzed the experience of public administration of educational districts, communal, autonomous and private general educational institutions. He also considered the mechanism of public influence on educational institutions management through public administrative structures, which are general meetings, by councils of educational institutions and councils of educational districts [1].

Parashchenko L. studied public administration of general secondary education development in Ukraine, including the problems of public administration [2].

Akhtamzyan N., Filipova V., Lypovetska O., Boguslavskiy M., Korsak K., Alferov Yu., Demchenko $\mathrm{O}$. and others studied foreign experience of education management.

L. Gaevska [3] and L. Prokopenko [4] studied the theoretical aspect of state and public education management.

Despite the big amount of research on the statepublic model of education management, many aspects of this topic are insufficiently covered, such as the role of local government in implementing this model, the issue of determining the legal basis for education management by local self-government bodies in Ukraine, the matter of implementing the principles of "a good self-government" in education management and the identification of studying and development needs of local council deputies, including rural ones.

In addition, there is a big amount of topics, which need a scientific evidence and development, such as the issue of regulatory and legal support for activities of local self-government bodies in the statepublic model of education management; the matter of subject and object features of the state-public model in education management; analyzing of education management peculiarities of local self-government bodies in foreign countries; the definition of the local self-government bodies' role in the state-public model of education management; substantiation of ways to introduce an effective state-public model of education management.

The purpose of the article is to determine effective mechanisms for the introduction of education public administration in Ukraine in the activities of the local self-government bodies.

Presentation of the base material. Over the last ten years, the issues of management democratization, optimal combination of centralization and decentralization in management, introduction of the state-public system of education management and public involvement in management decisions have been actively studied.

But today, there remain a number of unsolved issues, such as disclosure of the structure and powers of local self-government bodies and public associations in the state-public model of education management; implementation of a good self-government principles in education management at the local level; defining a clear structure of state and public education management bodies; development of mechanisms for financing each student from the state budget; substantiation of the autonomy of educational institutions that are within the competence of local governments; development of an electronic document management system and an electronic reporting system, etc.

Local self-government bodies, such as rural or city council, are the bodies which combine power and representative credentials. The state authorizes local governments to ensure state educational policy. The community is empowered to represent its interests and make decisions of local significance.

But the legislative framework which governs the education management issue at the local level needs 
to be improved. In particular, it is necessary to more clearly define the powers of local self-government bodies, separate them from the powers of local executive bodies, as well as to define the concept of "public administration of education" and the powers of civil society / community in education management at the local level.

The public administration of education is referred to the type of activity of the relevant authorities, the branch of public administration. The concept of "statepublic management of education" is considered as a kind of interaction between the state and society, as a process of combining the activities of the state and the community. The purpose of public administration of education is to meet educational needs and realize the right to access quality education.

During the years of independence, there remains a systemic problem of public administration in the field of education, such as the rigid hierarchy of education management bodies with concentration of power in the Ministry of Science and Education of Ukraine, which contradicts the announced intentions to build a state-public education management system.

There also can be seen the problem of duplication of functions of the Ministry of Science and Education of Ukraine and functions of local and regional authorities, "competence competition". We can also name such problems, as delegation of powers which contradicts the essence of local self-government (for example, providing textbooks to secondary school students) and inability of the majority of rural councils to fulfill the authority to manage education due to the lack of relevant structural subdivisions in the executive committees (in some cases even the individual fulfillment of the council executive body functions by the village head). Also, a significant problem is the inadequate funding of local governments to fulfill their powers.

In the education management system, regional departments do not deal with issues of education development, and are not the organizers of horizontal communication. As a result of these problems, there is no authority that would be responsible for the education quality.

Village and city councils are representative bodies of local self-government, who control their executive bodies. A deputy is a person who has a certain level of public trust and is authorized by the community to represent its interests. In order to make informed decisions, deputies must be competent in the relevant field, which makes it necessary to train them on the basis of the studied needs. Today, deputies of village councils have the right to advanced training, but they are still not covered by full-fledged training, which would help increase their level of competence for the exercise of deputy powers.

Local councils should assist deputies in their activities by creating appropriate conditions, such as providing documents, and reference materials necessary for the effective exercise of deputy powers and organizing of learning local council experience.

Considering the public as a subject of education management, we can see such problematic issue as fragmentation of territorial communities, which leads to the inability of the community to address issues of local importance and inconsistency of the public organizations' network development level with the criteria of advanced democracies, their insufficient level of influence in society and low level of public trust. There also can be seen such problems as unregulated interaction mechanisms of public organizations with government institutions and slow formation of civil society due to low activity of citizens, the distrust of their own ability to influence social processes.

The object of management is pre-school, secondary and non-school educational institutions. Among the main problems in the functioning of these institutions is inefficient funding. On the one hand, education is financed by residual principle, on the other hand, the presence of small schools in rural areas leads to significant budget expenditures (20.7 thousand hryvnias at a rate of 10.7 thousand hryvnias). As a result, the quality level of educational services is low, especially in rural areas.

Public self-government bodies operate in educational institutions, but their activities are more focused on local issues and they do not address longterm issues of education development.

Analysis of foreign experience shows that education in developed democracies is one of the priorities of the state and society. Approaches to governance and funding are not the same, but the tendency is that states guarantee free education and ensure equal access to quality education for their citizens.

There exist different mechanisms for education financing in each country, it can be funding of federal educational programs, full funding, educational subvention, targeted grants. The main source of funding in most countries is the state budget, as well as local budgets, EU regional funds, funds of founders of educational institutions [5].

In most foreign countries, such as the UK, Latvia, Germany, Poland, the USA, Finland and France education is managed in accordance with the principle 
of decentralization. Many functions performed by the state are transferred to local governments, public organisations and the private sector. This approach helps to involve the public in the management of educational institutions.

In foreign countries, parents are also involved in the educational process management. The scope of their authority ranges from adjusting the curriculum to advising the Ministry of Education. They also have rights to control the expenditure of financial resources.

Ukraine also has positive experience of involving the public in education management. The creation of various collegial bodies with real managerial powers will contribute to the effective solution of pressing issues and strengthen school autonomy.

A good self-government is very important, as local governments are the closest link of public administration to the citizens who provide them with basic services. At this level, members of the local community can feel involved in public activities.

The most common principles of "a good selfgovernment" found in the documents of various European institutions are participation, transparency and accountability. Ensuring citizen participation is a key element in guaranteeing the legitimacy of local government decisions. The availability and completeness of the necessary information will help to make effective decisions as well as to involve interested public representatives. Adherence to the principle of accountability provides an opportunity for the community to receive a report on the activities of local governments and to evaluate these activities, and to bring to justice, if necessary.

Today, local governments have some positive experience in involving the public. For example, holding consultations, establishing collegial bodies at local councils, holding public discussions and general meetings. In addition, some city councils are implementing "participation budget" programs aimed at involving city residents in the budget process by submitting projects to citizens and conducting open voting for such projects. It is clear that the budget in each city is different, but citizens know that they have a real opportunity to control the use of local budget funds and implement their own ideas that are useful for the city. Among the "participation budget" projects submitted by urban residents, a significant part is aimed at solving education problems at the local level.

Involving members of the local community in the implementation of joint projects contributes to the fact that the community not only participates in the decision-making process, but also actively participates in the implementation of decisions and assumes part of the responsibility for their implementation. The implementation of the basic principles of "a good self-government" in education management will contribute to the development of a state-public model of education management, in which the public will perform an advisory function. Local governments are one of the subjects of interaction between citizens and the state in the state-public model of education management.

Conclusions. Therefore, local governments and the public should become full actors in the education quality management at the local level, which in turn requires appropriate legislative changes. In addition, in order to strengthen civic activity, it is necessary to raise citizens' awareness of the civil society development, their ability to influence the government, as well as to carry out appropriate work to change the consumer attitude of citizens to the government. These measures will strengthen the relationship between local authorities and the local community, and will promote the development of a state-public model of quality management.

\section{Список літератури:}

1. Пастовенський О. В. Громадсько-державне управління загальною середньою освітою в регіоні : дис. ... д-ра пед. наук : 13.00.06 / О. В. Пастовенський. К., 2015. 438 с.

2. Паращенко Л. І. Механізми державного управління розвитком загальної середньої освіти в Україні : дис. ... д-ра наук з держ. упр. : спец. 25.00.02 / Л. І. Паращенко. К., 2012. 449 с.

3. Гаєвська Л. А. Розвиток державно-громадського управління загальною середньою освітою в Україні (друга половина XIX - початок XX століття) : автореф. дис. ... д-ра наук з держ. упр. : спец. 25.00.01 «Теорія та історія державного управління» / Л. А. Гаєвська. К., 2010. 39 с.

4. Прокопенко Л.Л. Ретроспектива адміністративно-територіальних реформ в Україні в контексті суспільної самоорганізації // Public administration aspects, 2015. № 5-6. C. 11-20.

5. Прокопенко К.Г., Ладонько Л.С., Філіпова Н.В. Дослідження досвіду зарубіжнихкраїн щодо активізації інноваційної діяльності у світлі євро інтеграційних процесів України // К.Г. Прокопенко, Л.С. Ладонько, Н.В. Філіпова. Чернігів: ЧДІЕУ, 2014. URL: http://ir.stu.cn.ua/handle/123456789/12835.

6. Гусєва П.T. Болонська декларація: завдання і реалізація основних принципів. URL: http:// dspace.univer.kharkov.ua/bitstream/123456789/5960/2/\%D0\%91\%D0\%BE\%D0\%BB\%D0\%BE\%D0\%BD\%D1 
$\% 81 \% \mathrm{D} 1 \% 8 \mathrm{C} \% \mathrm{D} 0 \% \mathrm{BA} \% \mathrm{D} 0 \% \mathrm{~B} 0 \% 20 \% \mathrm{D} 0 \% \mathrm{~B} 4 \% \mathrm{D} 0 \% \mathrm{~B} 5 \% \mathrm{D} 0 \% \mathrm{BA} \% \mathrm{D} 0 \% \mathrm{BB} \% \mathrm{D} 0 \% \mathrm{~B} 0 \% \mathrm{D} 1 \% 80 \% \mathrm{D} 0 \% \mathrm{~B} 0$ $\% \mathrm{D} 1 \% 86 \% \mathrm{D} 1 \% 96 \% \mathrm{D} 1 \% 8 \mathrm{~F} . \mathrm{pdf}$.

7. Семенець-Орлова I. Проблемні аспекти державного управління освітніми змінами. Вісник НАДУ при Президентові України. №2. 2015. С. 85-92.

8. Майборода С.В. Державне управління вищою освітою в Україні: структура, функції, тенденції розвитку (1917-1959 pр.) [Текст] : автореф. дис... д-ра наук з держ. управління: 25.00.01 / Майборода Сергій Васильович ; Українська академія держ. управління при Президентові України. К., 2002. 36 с.

\section{Reference}

1. Pastovens'kyj, O. V. (2015) “Hromads'ko-derzhavne upravlinnia zahal'noiu seredn'oiu osvitoiu v rehioni". Abstract of Ph.D. dissertation Theory and methods of education management. Kyiv, Ukraine.

2. Paraschenko, L. I. (2012) "Mekhanizmy derzhavnoho upravlinnia rozvytkom zahal'noi seredn'oi osvity v Ukraini". Abstract of Ph.D. dissertationMechanisms of public administration, Kyiv, Ukraine.

3. Haievs'ka, L. A. (2010) 'Rozvytok derzhavno-hromads'koho upravlinnia zahal'noiu seredn'oiu osvitoiu v Ukraini (druha polovyna KhIKh - pochatok KhKh stolittia)", Ph.D. Thesis, Theory and history of public administration, Kyiv, Ukraine.

4. Prokopenko, L.L. (2015) "Retrospektyva administratyvno-terytorial'nykh reform v Ukraini v konteksti suspil'noi samoorhanizatsii”, Publits administration aspetsts, vol. 5-6, pp. 11-20.

5. Prokopenko, K.H. Ladon'ko, L.S and Filipova, N.V. (2014) "Doslidzhennia dosvidu zarubizhnykhkrain schodo aktyvizatsii innovatsijnoi diial'nosti u svitli ievro intehratsijnykh protsesiv Ukrainy", Chernihiv: ChDIEU, URL: http://ir.stu.tsn.ua/handle/123456789/12835.

6. Husieva, P.T. "Bolons'ka deklaratsiia: zavdannia i realizatsiia osnovnykh pryntsypiv". URL: http:// dspatse.univer.kharkov.ua/bitstream/123456789/5960/2/\%D0\%91\%D0\%BE\%D0\%BB\%D0\%BE\%D0\%BD $\% \mathrm{D}$ $1 \% 81 \% \mathrm{D} 1 \% 8 \mathrm{Ts} \% \mathrm{D} 0 \% \mathrm{BA} \% \mathrm{D} 0 \% \mathrm{~B} 0 \% 20 \% \mathrm{D} 0 \% \mathrm{~B} 4 \% \mathrm{D} 0 \% \mathrm{~B} 5 \% \mathrm{D} 0 \% \mathrm{BA} \% \mathrm{D} 0 \% \mathrm{BB} \% \mathrm{D} 0 \% \mathrm{~B} 0 \% \mathrm{D} 1 \% 80 \% \mathrm{D} 0 \% \mathrm{~B}$ $0 \% \mathrm{D} 1 \% 86 \% \mathrm{D} 1 \% 96 \% \mathrm{D} 1 \% 8 \mathrm{~F} . \mathrm{pdf}$.

7. Semenets'-Orlova, I. (2015) "Problemni aspekty derzhavnoho upravlinnia osvitnimy zminamy", Visnyk NADU pry Prezydentovi Ukrainy, vol. 2, pp. 85-92.

8. Majboroda, S.V. (2002) "Derzhavne upravlinnia vyschoiu osvitoiu v Ukraini: struktura, funktsii, tendentsii rozvytku (1917-1959)", Ph.D. Thesis Public administration, National academy for public administration under the President of Ukraine, Kyiv, Ukraine.

\section{Грабовенко Н.В. Механізми впровадження державно-громадської моделі управління освітою в діяльність органів місцевого самоврядування}

В статті розглянуто механізми впровадження державно-громадської моделі управління освітою в діяльність органів місцевого самоврядування. Доведено, що управління освітою потребує постійного удосконалення та модернізаиії, а децеентралізаиія, демократизащія, становлення громадянського суспільства як процеси розвитку краӥни, ставлять на порядок денний формування та розвиток держсавно-громадської моделі управління освітою, механізмів ї̈ впровадження в діяльність органів місцевого самоврядування.

Визначено необхідність формування теоретико-методологічних засад дослідження ролі органів місиевого самоврядування у державно-громадській моделі управління освітою в Україні, вивчення зарубіжного досвіду участі місиевих громад у виріменні освітніх проблем, визначення нових підходів до управління всією освітньою діяльністю, особливо на місиевому рівні, визначення та аналіз умов, за яких діяльність органів місиевого самоврядування у запровадженні нової моделі управління освітою буде ефективною.

Уточнено поняття «державно-громадське управління освітою» як вид взаємодії держави і суспільства, процес поєднання діяльності держави і громади. Визначено мету державно-громадського управління освітою - задоволення освітніх потреб та реалізація права на доступ до якісної освіти.

Аналізується зарубіжний та вітчизняний досвід управління освітою на регіональному рівні. 3'ясовано, що на сьогодні органи місиевого самоврядування мають певний позитивний досвід щодо залучення громадськості, проведення консультацій, створення колегіальних органів при місцевих радах, проведення громадських обговорень та загальних зборів.

Доведено, що управління освітою в більшості зарубіэниих краӥн (Велика Британія, Латвія, Німеччина, Польща, США, Фінляндія, Франщія) здійснюється з дотриманням приниипу дещентралізащії з передачею більшості функиій держсави на рівень місиевих органів влади, громадських організацій $i$ приватного сектора.

Ключові слова: освіта, державно-громадське управління освітою, якість освіти, місиеве самоврядування. децентралізація управління освітою. 